\title{
Integrin $\alpha^{2}$ Cytoplasmic Domain Deletion Effects: Loss of Adhesive Activity Parallels Ligand-independent Recruitment into Focal Adhesions
}

\author{
Satoshi Kawaguchi,* Jeffrey M. Bergelson, Robert W. Finberg, and \\ Martin E. Hemler
}

Dana-Farber Cancer Institute, Harvard Medical School, Boston, Massachusetts 02115

Submitted June 8, 1994; Accepted July 25, 1994

Monitoring Editor: Richard Hynes

\begin{abstract}
Chinese hamster ovary (CHO) cells transfected with the integrin $\alpha^{2}$ subunit formed a stable VLA-2 heterodimer that mediated cell adhesion to collagen. Within CHO cells spread on collagen, but not fibronectin, wild-type $\alpha^{2}$ subunit localized into focal adhesion complexes (FACs). In contrast, $\alpha^{2}$ with a deleted cytoplasmic domain was recruited into FACs whether $\mathrm{CHO}$ cells were spread on collagen or fibronectin. Thus, as previously seen for other integrins, the $\alpha^{2}$ cytoplasmic domain acts as a negative regulator, preventing indiscriminate integrin recruitment into FACs. Notably, ligand-independent localization of the VLA- $2 \alpha^{2}$ subunit into FACs was partially prevented if only one or two amino acids were present in the $\alpha^{2}$ cytoplasmic domain (beyond the conserved GFFKR motif) and was completely prevented by four to seven amino acids. The addition of two alanine residues (added to GFFKR) also partially prevented ligand-independent localization. In a striking inverse correlation, the same mutants showing increased ligand-independent recruitment into FACs exhibited diminished $\alpha^{2}$-dependent adhesion to collagen. Thus, control of VLA-2 localization may be closely related to the suppression of cell adhesion to collagen. In contrast to FAC localization and collagen adhesion results, VLA-2-dependent binding and infection by echovirus were unaffected by either $\alpha^{2}$ cytoplasmic domain deletion or exchange with other cytoplasmic domains.
\end{abstract}

\section{INTRODUCTION}

Cell adhesion mediated by cell surface $\alpha \beta$ heterodimers in the integrin family is dynamically controlled by "inside-out" signaling (Springer, 1990; Ginsberg et al., 1992; Hynes, 1992). This process allows for the maintenance of variable states of constitutive adhesive activity in different cell types and for modulation of adhesive activity in response to cell stimulation or during differentiation. Integrin cytoplasmic domains play key roles in the inside-out signaling process (Ginsberg et al., 1992; Hemler et al., 1994). Mutation of critical residues within $\beta_{3}$ (Chen et al., 1992; O'Toole et al., 1994) or $\beta_{2}$ (Hibbs et al., 1991a) cytoplasmic domains causes loss of adhesive activity, and partial deletions of $\beta_{2}$ (Hibbs et al., $1991 b ;$ Rabb et al., 1993) or $\beta_{1}$ (Hayashi et al., 1990)

\footnotetext{
* Current address: Department of Orthopedic Surgery, Sapporo Medical University School of Medicine, Sapporo 060, Japan
}

cytoplasmic domains also causes loss of adhesion. Overall, the $\beta_{1}, \beta_{2}, \beta_{3}$, and $\beta_{5}$ chains appear to be interchangeable in their abilities to mediate inside-out signaling (Solowska et al., 1991; Pasqualini and Hemler, 1994; O'Toole et al., 1994), consistent with their 20$60 \%$ similarities in tail sequence.

The cytoplasmic domains of integrin $\alpha$ chains also play critical roles in determining adhesive activity. Deletion of the $\alpha^{2}$ (Kawaguchi and Hemler, 1993; Kassner et al., 1994), $\alpha^{4}$ (Kassner and Hemler, 1993; Kassner et al., 1994), $\alpha^{v}$ (Filardo and Cheresh, 1994), or $\alpha^{6}$ (Shaw and Mercurio, 1993) tails after the highly conserved GFFKR motif caused a loss of adhesive activity for each, suggesting that these domains generally play a positive role. Despite having sequences that are quite distinct, the tails of several $\alpha$ chains are interchangeable $\left(\alpha^{2}, \alpha^{4}\right.$, $\alpha^{5}$ [Kassner and Hemler, 1993; Kawaguchi and Hemler, 1993; Kassner et al., 1994]; $\alpha^{6 \mathrm{~A}}, \alpha^{6 \mathrm{~B}}$ [Delwel et al., 1993; Shaw et al., 1993]) with respect to their positive con- 
tributions toward cell adhesion. In fact, the specific sequence seems less important than the tail length, which needs to include up to four to seven residues after GFFKR for optimal adhesive activity (Kassner et al., 1994). Also, the deficiency in cell adhesion because of $\alpha$ chain tail deletion can be dramatically enhanced or suppressed, depending on the type and amount of divalent cations utilized and the degree of constitutive activity of the cell type analyzed (Kassner et al., 1994). These considerations may help to reconcile some of the diverse $\alpha$ chain deletion results seen from other laboratories (Hibbs et al., 1991b; Briesewitz et al., 1993; Bauer et al., 1993).

The mechanism whereby $\alpha$ chain tails support cell adhesion is not entirely clear. However, it is known that manipulation of $\alpha$ chain tails can alter integrin conformation and ligand-binding affinity (O'Toole et al., 1991, 1994), as well as susceptibility to stimulation by phorbol esters (Kassner and Hemler, 1993; Kawaguchi and Hemler, 1993), even though the latter process may not involve changes in ligand-binding affinity (Danilov and Juliano, 1989; Faull et al., 1994). Also, it has been found that the effects of $\alpha$ chain deletion (after GFFKR) are lost in the presence of metabolic energy inhibitors or upon integrin solubilization, suggesting that an active cellular process is needed for $\alpha$ chain tails to exert their positive effects (Kassner et al., 1994).

Integrin $\alpha$ chain tails also play key roles in regulating the outside-in signaling that occurs subsequent to ligand binding. For example, the type of $\alpha$ chain tail can variably influence cell migration and collagen gel contraction (Chan et al., 1992). One postligand-binding event that occurs for many integrins is the organization of focal adhesion complexes (Turner and Burridge, 1991). The integrin $\beta_{1}$ chain by itself has the capability to be recruited into focal adhesion complexes (FACs), whereas the $\alpha$ chain alone does not (LaFlamme et al., 1992). Rather, the $\alpha^{\mathrm{Ilb}}$ (Ylänne et al., 1993) and $\alpha^{1}$ (Briesewitz et al., 1993) cytoplasmic domains appear to act as negative regulators, preventing integrin recruitment into preformed FACs. The critical regions within those $\alpha$ chains that confer negative regulatory activity have not yet been identified.

Here, we have analyzed the cytoplasmic domain of $\alpha^{2}$ and determined that it also plays a negative regulatory role in restricting integrin recruitment into FACs. Then, we have utilized a series of $\alpha^{2}$ cytoplasmic tail mutants to identify the critical residues needed for regulation of FAC recruitment. Thus, we were able to determine whether these were the same residues that exert a positive influence on cell adhesion.

Previously, it was shown that both echovirus 1 (Bergelson et al., 1992) and echovirus 8 (Bergelson et al., 1993b) utilize VLA-2 as a cell surface receptor. Although the mechanism of this interaction was different from VLA-2 interactions with collagen and laminin (Bergelson et al., 1993a), both virus and the extracellular matrix ligands bind within the I-domain region of VLA-2 (Bergelson et al., 1994; Kamata et al., 1994). Here, we reasoned that if $\alpha$ chain cytoplasmic domains could exert dramatic influence over integrin-mediated adhesion and subcellular distribution, then there was a strong possibility that they might also influence echovirus binding and/or infection and replication. Thus, we have analyzed $\alpha^{2}$-cytoplasmic domain mutants to determine whether any of the latter events are also influenced by the $\alpha^{2}$ tail.

\section{MATERIALS AND METHODS}

\section{Antibodies and Matrix Proteins}

Monoclonal antibodies (mAbs) utilized were anti- $\alpha^{2}, 12 \mathrm{~F} 1$ (Pischel et al., 1987), 5E8 (Chen et al., 1991), and IIIE9 (Bergelson et al., 1994); anti-hamster $\alpha^{5}$, PB1 (Brown and Juliano, 1985); anti-hamster $\beta_{1}, 7 \mathrm{E} 2$ (Brown and Juliano, 1988); and negative controls, J-2A2 (Hemler and Strominger, 1982) and P3 (Lemke et al., 1978). Rabbit anti-phosphotyrosine antibody was obtained from Transduction Laboratories (Lexington, $K Y$ ). Rat collagen type I was purchased from Collaborative Biomedical Products (Bedford, MA), and human fibronectin was from GIBCO-BRL (Gaithersberg, MD).

\section{Construction and Transfection of Mutant Forms of VLA-2 $\alpha$ Subunit}

All mutant forms of the $\alpha^{2}$ subunit used in this study (Table 1) were constructed by polymerase chain reaction (PCR) as described elsewhere (Kassner et al., 1994). The mutant antisense oligo (TTGGTTCTAGATTACTATTTTCTTTTGAAGA), which contains two consecutive stop codons followed by an $\mathrm{Xba}$ I restriction site placed at amino acid position 1133, was used for the construction of $\alpha^{2}-1133$. Similarly, the oligonucleotide (GCTCTAGACTATTAATATTTTCTTTTGA) was used to construct the deletion mutant, $\alpha^{2}-1134$. To construct the $\mathrm{X} 2 \mathrm{C} 0$ A chimeric mutant, an oligonucleotide was designed (GCTCTAGATTATGCTCTTTTGAAGAAGCCG) consisting of a region complementary to the GFFKR motif, followed by an alanine codon, one stop codon, and $\mathrm{Xba}$ I restriction site. For the $\alpha^{2} \mathrm{X} 2 \mathrm{C} 0$-AA mutant, a similar oligonucleotide (GCTCTAGATTAAGCTGCTCTTTTGAAGAAGCCG) was used, except that it contained two consecutive alanine codons. Each oligonucleotide mentioned above was paired with the oligonucleotide (CAAGCCTTAAGTGAAAGCCAAGAAA) containing a unique AflII ${ }^{2784}$ restriction site, and PCR was carried out using CDNA for $\alpha^{2}$ subunit (Takada and Hemler, 1989). During the PCR procedure, an irrelevant $\mathrm{Glu} \rightarrow$ Lys mutation was introduced at amino acid position 890 within the extracellular domain of the $\alpha^{2}-1133,-1134,-X 2 \mathrm{C} 0-\mathrm{A}$, and $-\mathrm{X} 2 \mathrm{C} 0-\mathrm{AA}$ mutants. Previously it was shown that this mutation has no effect on VLA-2-dependent cell adhesion (Kassner et al., 1994). Constructs were cloned into a unique Sal I-Xba I site in the pECE expression vector (Giancotti and Ruoslahti, 1990) then cotransfected into CHO dfhr cells together with the plasmid pMDR901 (a gift of Dr. M. Rosa, Biogen, Cambridge MA) as described elsewhere (Bergelson et al., 1993b; Pasqualini et al., 1993). Transfectants were selected in MEM- $\alpha$ media with $10 \%$ dialyzed fetal bovine serum (Hazleton, Herndon, VA) and enriched for $\alpha^{2}$ expression by fluorescence-activated cell sorting using the anti- $\alpha^{2} \mathrm{mAb}, 12 \mathrm{~F} 1$. Other $\alpha^{2}$ mutants shown in Table 1 were generated and expressed in $\mathrm{CHO}$ cells as described elsewhere (Kassner et al., 1994).

\section{Flow Cytometry and Immunoprecipitation}

For flow cytometry, cells $\left(3-5 \times 10^{5}\right)$ were stained with negative control $\mathrm{mAb}$ or anti- $\alpha^{2} \mathrm{mAb}$, followed by fluorescein isothiocyanate (FITC)conjugated goat anti-mouse IgG (Calbiochem, La Jolla, CA), and then analyzed using a FACScan machine (Becton Dickinson, Mountainview, 
CA) as described elsewhere (Elices et al., 1990). For immunoprecipitation, cells $\left(2 \times 10^{6}\right.$ per sample) were surface labeled with ${ }^{125} \mathrm{I}$ using lactoperoxidase and lysed with $1 \%$ Triton $X-100$ in phosphate buffered saline (PBS) containing phenylmethylsulfonyl fluoride and $1 \mathrm{mM}$ $\mathrm{MgCl}_{2}$ as described elsewhere (Hemler et al., 1987). Nonreducing sodium dodecyl sulfate-polyacrylamide gel electrophoresis was carried out on $7 \%$ polyacrylamide gels.

\section{Immunofluorescence Microscopy}

Circular glass coverslips (12 mm, Fisher Scientific, Pittsburgh, PA) were coated overnight at $4^{\circ} \mathrm{C}$ with 20 or $100 \mu \mathrm{g} / \mathrm{ml}$ of fibronectin, and then nonspecific sites were blocked with PBS containing $1 \%$ heatdenatured bovine serum albumin (HBSA) for $30 \mathrm{~min}$ at $37^{\circ} \mathrm{C}$. Cells were harvested with $1 \mathrm{mM}$ EDTA in PBS, washed twice with Eagle's minimum essential medium (MEM)- $\alpha^{-}$, and resuspended in MEM- $\alpha^{-}$ media. Then $5 \times 10^{4}$ cells were plated on glass coverslips and incubated at $37^{\circ} \mathrm{C}$ for $2 \mathrm{~h}$. Cells were then fixed with $1.5 \%$ paraformaldehyde for $20 \mathrm{~min}$ at room temperature and permeabilized with $0.5 \%$ Triton $X-100$ in PBS for $2 \mathrm{~min}$ at room temperature. In another experiment, cells were preincubated in MEM- $\alpha^{-}$containing $25 \mu \mathrm{g} / \mathrm{ml}$ of cycloheximide (Sigma, St. Louis, MO) for $2 \mathrm{~h}$ at $37^{\circ} \mathrm{C}$ before harvesting then seeded on coverslips in MEM- $\alpha$ media containing cycloheximide $(25 \mu \mathrm{g} / \mathrm{ml})$ to block endogenous matrix production. For staining, fixed cells were incubated with $20 \%$ fetal calf serum and $1 \%$ human serum in PBS for $2 \mathrm{~h}$ at $4{ }^{\circ} \mathrm{C}$ and then incubated with primary antibodies in PBS containing $5 \%$ human serum for $1 \mathrm{~h}$ at room temperature. Rabbit anti-phosphotyrosine antibody was used as a positive control to detect FACs, and $\alpha^{2}$ localization was detected using the mAbs IIIE9 or 5E8. Negative control mAb, J-2A2; anti-hamster $\alpha^{5} \mathrm{MAb}, \mathrm{PB} 1$; and antihamster $\beta_{1}, 7 \mathrm{E} 2$ were also used. After washing twice with PBS, cells were double stained with both FITC-conjugated goat anti-mouse IgG and rhodamine-conjugated goat anti-rabbit IgG (Calbiochem) for 30 $\mathrm{min}$ at room temperature. The coverslips were washed twice with PBS and once with water and mounted on slides with FluorSave mounting media (Calbiochem). The specimens were examined using a Zeiss Axioskop fluorescence microscope (Carl Zeiss, Thornwood, NY), and photographs were taken on Kodak Tri-X pan 400 film (Rochester, NY). The approximate number of cells showing focal contact formation was counted from three high power microscopic fields (100-130 spread cells were counted in each field).

\section{Adhesion Assays}

Cell attachment to matrix proteins was estimated as described previously (Kawaguchi and Hemler, 1993). Briefly, cells were labeled with the fluorescent dye BCECF-AM [2', 7'-bis (2-carboxyethyl)-5(6)carboxyflorescein] (Molecular Probes, Eugene, OR), washed once with $1 \mathrm{mM}$ EDTA in PBS and once with Tris-buffered saline (TBS), and then resuspended in TBS containing $0.1 \%$ HBSA and $2 \mathrm{mM}$ glucose. Cells $\left(5 \times 10^{4} /\right.$ well $)$ in the presence of varied concentrations of $\mathrm{MgCl}_{2}$ were added to 96-well microtiter plates (Flow Laboratories, McLean, VA) that had been coated with $5 \mu \mathrm{g} / \mathrm{ml}$ of collagen and blocked with TBS containing $0.1 \%$ HBSA. After $30 \mathrm{~min}$ incubation, unbound cells were washed away with prewarmed TBS, and cells remaining attached to the plate were analyzed using a CytoFluor 2300 fluorescence analyzer machine (Millipore, Bedford, MA). Assays are reported as the mean \pm SD of triplicate determinations.

\section{RESULTS}

\section{Expression of $\alpha^{2}$ Mutant Constructs}

For comparative studies of VLA-2 distribution and function, we expressed wild-type and several mutant forms of the $\alpha^{2}$ subunit in Chinese hamster ovary (CHO) cells (Table 1). Flow cytometric analysis using anti- $\alpha^{2}$ $\mathrm{mAb}$ (Figure 1) confirmed that deletion mutants $\left(\alpha^{2}-\right.$
Table 1. List of $\alpha^{2}$ cytoplasmic domain mutants

\begin{tabular}{ll}
\hline$\alpha^{2}$ constructs & Cytoplasmic tail sequence \\
\hline X2C2 (wt) & KLGFFKRKYEKMTKNPDEIDETTELSS \\
1146 & KLGFFKRKYEKMTKNPDEIDE \\
1139 & KLGFFKRKYEKMTK \\
1136 & KLGFFKRKYEK \\
1134 & KLGFFKRKY \\
1133 & KLGFFKRK \\
X2CO (1132) & KLGFFKR \\
X2CO-AA & KLGFFKRAA \\
X2CO-A & KLGFFKRA \\
\hline
\end{tabular}

$\left.1133, \alpha^{2}-1134\right)$ and deletion mutants with alanine substitutions ( $\mathrm{X} 2 \mathrm{C} 0-\mathrm{A}, \mathrm{X} 2 \mathrm{C} 0-\mathrm{AA})$ were expressed on the surface of $\mathrm{CHO}$ cells at a level equivalent to wild-type $\alpha^{2}$ (X2C2), whereas no reactivity to anti- $\alpha^{2} \mathrm{mAb}$ was observed on mock (pMDR-901 alone)-transfected CHO cells. Comparable levels of expression of other deletion mutants including $\alpha^{2}-1132$ (also called X2C0), $\alpha^{2}-1136$, $\alpha^{2}-1139$, and $\alpha^{2}-1146$ were obtained previously (Kassner et al., 1994).

Immunoprecipitation experiments showed that each of the mutated human $\alpha^{2}$ subunits associated with the endogenous hamster $\beta_{2}$ subunit to form a typical heterodimeric VLA-2 structure (Figure 2). The anti- $\alpha^{2} \mathrm{mAbs}$ 12F1 and IIIE9 each recognized comparable levels of $\alpha^{2} \beta_{1}$ heterodimer from CHO transfectants (Figure 2, lanes $d-h$ and $j-n$ ) but not from mock-transfected $\mathrm{CHO}$ cells (lanes $\mathrm{c}$ and $\mathrm{i}$ ). These immunoprecipitations of $\mathrm{mu}$ tant $\alpha^{2}$ with $\beta_{1}$ look identical to wild-type $\alpha^{2} \beta_{1}$ seen many times previously (Elices and Hemler, 1989; Chan et al., 1991, 1992; Kawaguchi and Hemler, 1993). A control $\mathrm{mAb}$ yielded no integrin bands (lane $\mathrm{a}$ ), and the anti-hamster $\beta_{1}$ MAb immunoprecipitated integrins (mostly $\alpha^{5} \beta_{1}$ ) endogenously expressed in $\mathrm{CHO}$ cells (lane b).

\section{$\alpha^{2}$ Cytoplasmic Domain Effects During Cell Spreading on Collagen}

After cell spreading on collagen, both wild-type $\alpha^{2}$ (X2C2) (Figure 3, left panels) and fully deleted $\alpha^{2}$ (X2C0) (Figure 3, right panels) showed similar localization into typical FACs (Figure 3). For each $\alpha^{2}$ CHO transfectant, two examples are shown (top and bottom panels). Although FAC formation was similar for the $\mathrm{X} 2 \mathrm{CO}$ and $\mathrm{X} 2 \mathrm{C} 2$ proteins, a substantially smaller fraction of the $\mathrm{X} 2 \mathrm{C} 0$-transfected $\mathrm{CHO}$ cells actually spread on collagen. That result is totally consistent with the diminished adhesive capacity of $\mathrm{X} 2 \mathrm{C} 0-\mathrm{CHO}$ cells as shown below in Figure 8 and elsewhere (Kawaguchi and Hemler, 1993; Kassner et al., 1994).

\section{$\alpha^{2}$ Cytoplasmic Domain Effects During Cell Spreading on Fibronectin}

To determine whether the cytoplasmic domain of $\alpha^{2}$ plays a role in the regulation of indiscriminate VLA-2 


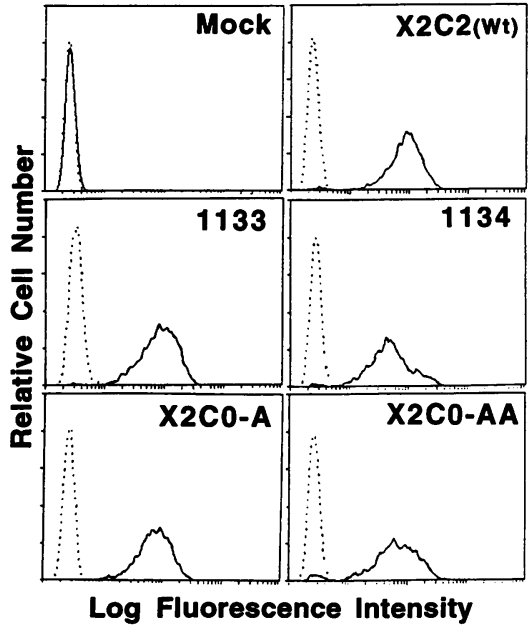

Figure 1. Surface expression of $\alpha^{2}$ mutants transfected into $\mathrm{CHO}$ cells. Transfected $\mathrm{CHO}$ cells were stained using the anti- $\alpha^{2} \mathrm{mAb} 12 \mathrm{~F} 1$ $(-)$ or the negative control mAb J-2A2 (- - -), and $\alpha^{2}$ levels were assessed by flow cytometry as described in MATERIALS AND METHODS.

recruitment into focal adhesion sites formed by other integrins, we examined wild-type $\alpha^{2}$ (X2C2) and fully deleted $\alpha^{2}(\mathrm{X} 2 \mathrm{C} 0)$ in $\mathrm{CHO}$ cells spread on fibronectin. As shown in Figure 4A, wild-type VLA-2 in CHO cells failed to localize into focal adhesion sites and remained diffuse, even though FACs were indeed present in the same cell as shown by double staining with an antiphosphotyrosine antibody (Figure 4C). The formation of those FACs was likely dependent on endogenous hamster $\alpha^{5} \beta_{1}$, because the focal adhesion sites were stained with both anti-hamster $\beta_{1} \mathrm{mAb}$ (Figure $4 \mathrm{E}$ ) and anti-hamster $\alpha^{5} \mathrm{mAb}$.

Compared to wild-type $\alpha^{2}$, distribution of X2C0 was strikingly different. In $\mathrm{X} 2 \mathrm{C} 0$-transfected $\mathrm{CHO}$ cells, FACs were clearly double-stained with both anti- $\alpha^{2}$ $\mathrm{mAb}$ (Figure 4B) and anti-phosphotyrosine $\mathrm{Ab}$ (Figure $4 \mathrm{D})$. The hamster $\beta_{1}$ subunit also localized at focal adhesion sites in $\mathrm{X} 2 \mathrm{C} 0$-transfected $\mathrm{CHO}$ cells spread on fibronectin (Figure 4F). The more intense staining of $\beta_{1}$ in Figure $4 \mathrm{~F}$ compared to $4 \mathrm{E}$ is probably because both $\alpha^{5} \beta_{1}$ and $\alpha^{2} \beta_{1}$ are present in FACs in $4 \mathrm{~F}$, whereas the $\alpha^{2} \beta_{1}$ is absent in $4 \mathrm{E}$. With a negative control antibody, no FAC staining was seen in either X2C2- or $\mathrm{X} 2 \mathrm{C} 0$-transfected $\mathrm{CHO}$ cells. In another experiment, the X2C0 protein, but not wild-type $\alpha^{2}$, was recruited into FACs formed when $\mathrm{CHO}$ cells spread on vitronectin. Thus, the $\alpha^{2}$ subunit cytoplasmic domain prevents VLA2 from being recruited into focal adhesion sites formed by other integrins.

Whereas the anti- $\alpha^{2}$ mAb IIIE9 stained both $\mathrm{X} 2 \mathrm{C} 2$ and $\mathrm{X} 2 \mathrm{C} 0$ present in FACs formed on collagen or fibronectin (Figures 3 and 4B), the anti- $\alpha^{2}$ mAb 5E8 preferentially stained $\mathrm{X} 2 \mathrm{C} 0$ in FACs formed on fibronectin but not on collagen. Presumably, collagen bind-

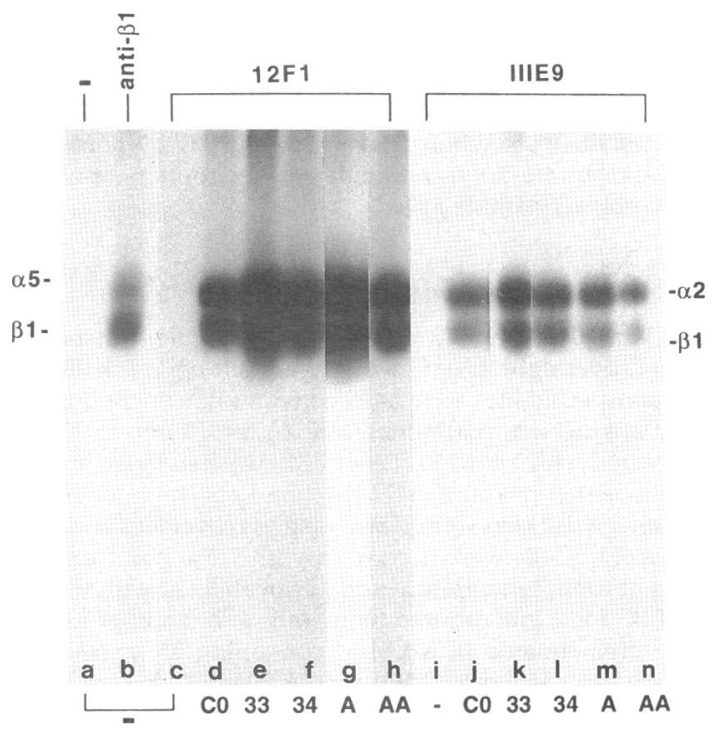

Figure 2. Immunoprecipitation of VLA-2 from $\mathrm{CHO}$ transfectants. Equivalent numbers of transfected $\mathrm{CHO}$ cells were radiolabeled with ${ }^{125} \mathrm{I}$, extracted with Triton $\mathrm{X}-100$, and then immunoprecipitated using anti- $\alpha^{2}$ mAbs 12F1 (lanes c-h) and IIIE9 (lanes $\left.i-n\right)$. Also shown are immunoprecipitations with the control $\mathrm{mAb}$ P3 (lane a) and antihamster $\beta_{1}$ mAb 7E2 (lane b) from mock-transfected $\mathrm{CHO}$ cells. The labels -, $\mathrm{CO}, 33,34, \mathrm{~A}$, and AA correspond to mock-transfected $\mathrm{CHO}$ cells, X2C0, $\alpha^{2}-1133, \alpha^{2}-1134, \mathrm{X} 2 \mathrm{C} 0$-A, and X2C0-AA transfectants, respectively.
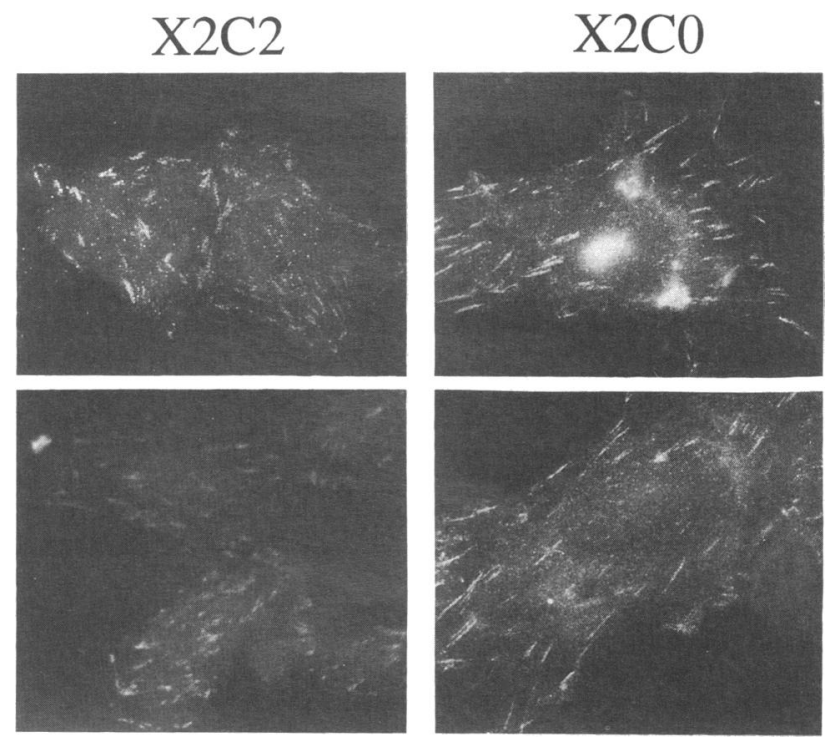

Figure 3. Subcellular localization of wild-type $\alpha^{2}$ and X2C0 on collagen. CHO cells were transfected with wild-type $\alpha^{2}$ (X2C2, left panels) or with $\alpha^{2}$ that had a fully deleted cytoplasmic domain (X2C0, right panels). Cells were cultured for $5 \mathrm{~h}$ on coverslips precoated with 100 $\mu \mathrm{g} / \mathrm{ml}$ of collagen. After fixation and permeabilization, cells were stained with anti- $\alpha^{2}$ mAb IIIE9 and visualized with FITC-conjugated anti-mouse IgG. Pictures of $\mathrm{X} 2 \mathrm{C} 2 \mathrm{CHO}$ cells were taken at $640 \times$ magnification, and $\mathrm{X} 2 \mathrm{C} 0$ cells were at $1000 \times$ magnification. 
Figure 4. Subcellular localization of wild-type $\alpha^{2}$ and $\mathrm{X}_{2} \mathrm{CO}$ on fibronectin. CHO cells transfected with wild-type $\alpha^{2}$ (X2C2, A, C, and E) or the cytoplasmic deletion mutant $(\mathrm{X} 2 \mathrm{C} 0, \mathrm{~B}, \mathrm{D}$, and $F$ ) were cultured for $2 \mathrm{~h}$ on coverslips precoated with $100 \mu \mathrm{g} / \mathrm{ml}$ of fibronectin. After fixation and permeabilization, the cells were double stained with anti- $\alpha^{2}$ mAb IIIE9 (A and B) and polyclonal anti-phosphotyrosine antibody (C and D). The staining of anti- $\alpha^{2} \mathrm{mAb}$ was visualized by FITC-conjugated anti-mouse IgG, and the phosphotyrosine antibody was detected with Rhodamine-conjugated anti-rabbit IgG. In a separate experiment, the cells cultured on fibronectin were stained with anti-hamster $\beta_{1} \mathrm{mAb}$ 7E2 (E and F). Pictures are at $1000 \times$ magnification.
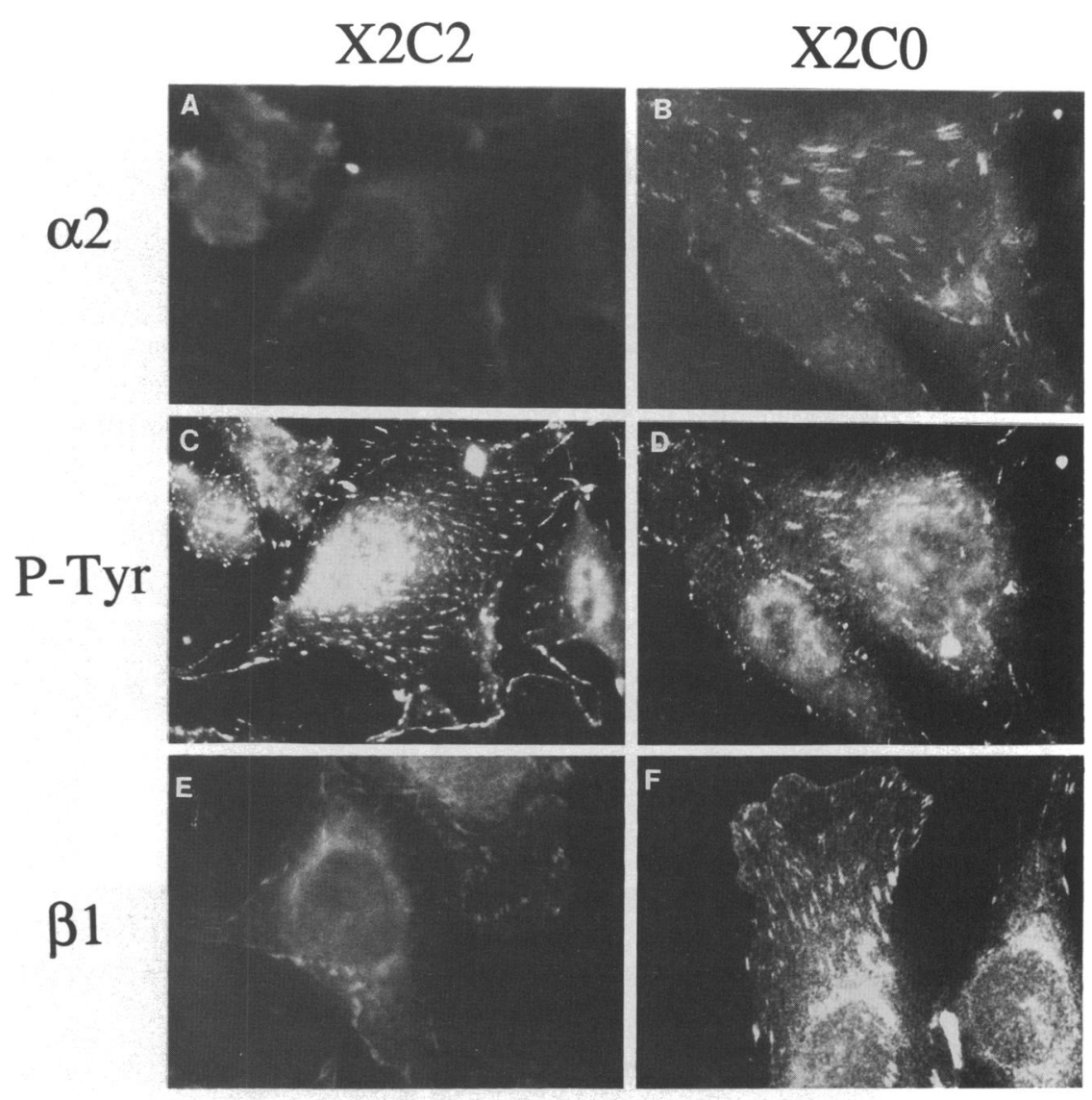

ing to VLA-2 excludes the 5E8 antibody, a known VLA2 function blocker, whereas $5 E 8$ is not excluded from fibronectin FACs, because fibronectin is not a ligand for VLA-2.

\section{Cytoplasmic Domain Residues Involved in Regulation of VLA Localization}

To identify the specific residues in the $\alpha^{2}$ cytoplasmic domain responsible for regulation of VLA-2 localization on fibronectin, we evaluated each of the $\alpha^{2}$ cytoplasmic domain mutants shown in Table 1 . In CHO cells spread on fibronectin, the focal adhesion sites contained $\alpha^{2}$. 1133 (Figure 5A), $\alpha^{2}-1134$ (Figure 5C), X2C0-A (Figure $5 \mathrm{E}$ ), and $\mathrm{X} 2 \mathrm{C0}-\mathrm{AA}$ (Figure 5G). Also for each $\alpha^{2}$ mutant, double-staining revealed colocalization with phosphotyrosine (Figure 5, B, D, F, and H). Thus, one to two amino acids beyond the GFFKR motif was not sufficient to prevent ligand-independent localization into FACs.

In contrast, when four amino acids were present after the GFFKR motif (as in $\alpha^{2}-1136$ ), immunoreactivity of anti- $\alpha^{2} \mathrm{mAb}$ at focal adhesion sites was markedly decreased (Figure 6A), even though FACs were clearly present as shown by staining with anti-phosphotyrosine antibody (Figure 6B). Other deletion mutants with more amino acids such as $\alpha^{2}-1139$ (Figure 6C) and $\alpha^{2}-1146$
(Figure 6E) also were excluded from FACs, even though such sites were clearly present (Figure 6, D and F).

\section{Inverse Correlation Between Adhesive Activity and Ligand Independent Recruitment into FACs}

We next tested the adhesive property of $\mathrm{CHO}$ transfectants to determine the effect of specific $\alpha^{2}$ cytoplasmic domain residues on regulation of VLA-2 adhesive function. Previously we found that ED50 values from divalent cation titration curves were an excellent indicator of the relative functional activity of an integrin (Kassner et al., 1994). As shown in Figure 7A, titration over a range of $\mathrm{Mg}^{2+}$ concentrations (at a constant ligand dose of $5 \mu \mathrm{g} / \mathrm{ml}$ collagen) yielded an ED50 value for $\mathrm{CHO}$ $\mathrm{X} 2 \mathrm{C} 0$ cells that was 15 -fold greater than that for $\mathrm{CHO}$ $\mathrm{X} 2 \mathrm{C} 2$ cells. Thus, VLA-2 containing the $\mathrm{X} 2 \mathrm{C} 0$ mutant utilizes divalent cation less efficiently to support adhesion, consistent with it being less active than X2C2. Notably, ED50 values obtained with $\mathrm{CHO}-1133$ and $\mathrm{CHO}-$ 1134 cells were intermediate between $\mathrm{CHO}-\mathrm{X} 2 \mathrm{C} 2$ and $\mathrm{CHO}-\mathrm{X} 2 \mathrm{CO}$ cells (Figure 7A). Thus, only one to two amino acids after the GFFKR motif were sufficient to cause partial recovery of adhesive activity. This result extends the previous finding that seven or more amino acids were required to confer maximal adhesive activity 

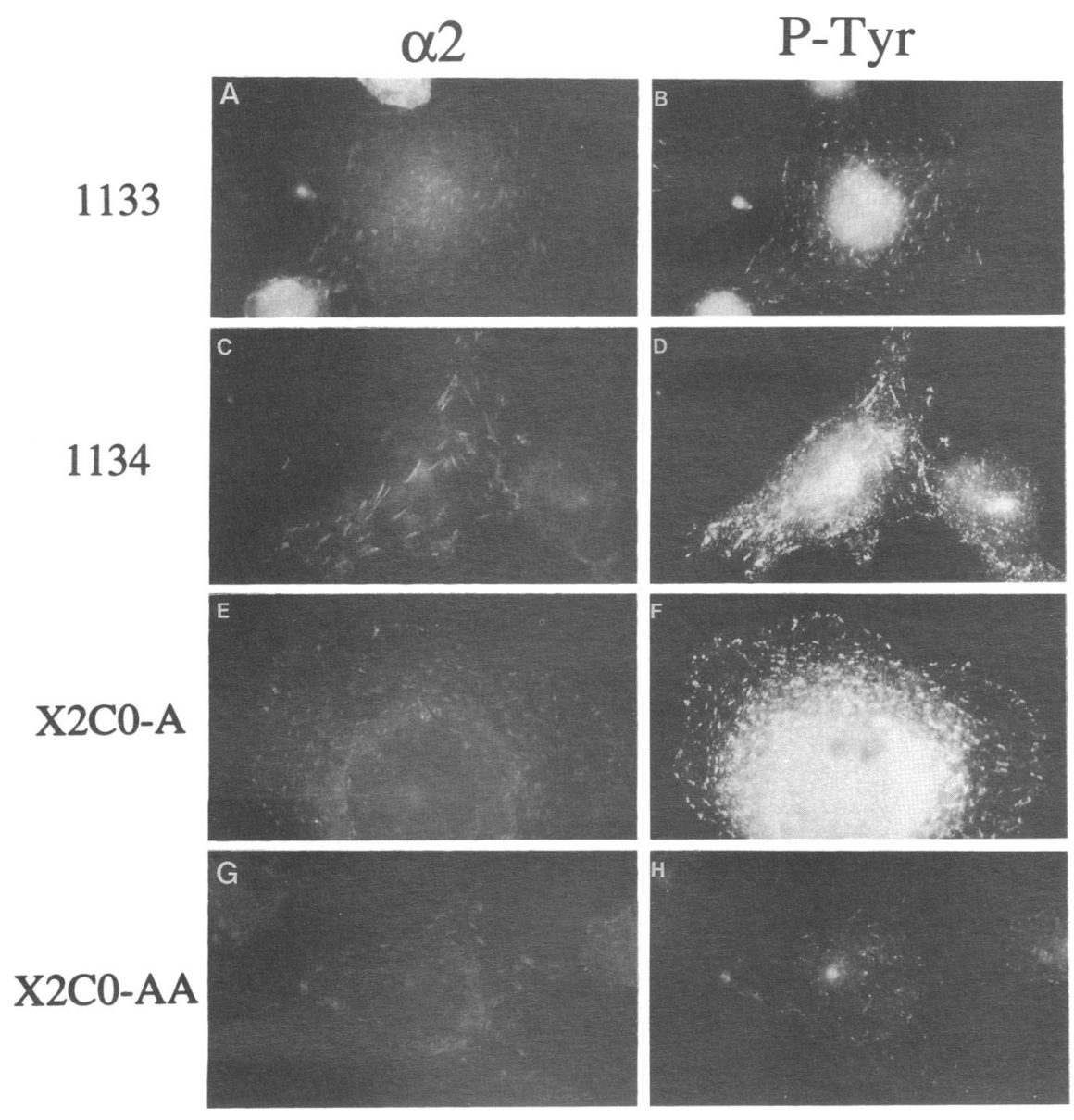

Figure 5. Recruitment of short $\alpha^{2}$ mutants into FACs on fibronectin. $\mathrm{CHO}$ cells were transfected with $\mathrm{X} 2 \mathrm{C} 0-\mathrm{A}$ (A and $\mathrm{B}), \mathrm{X} 2 \mathrm{C} 0$ AA (C and D), $\alpha^{2}-1133$ (E and F), and $\alpha^{2}$ 1134 ( $\mathrm{G}$ and $\mathrm{H})$. Cells were cultured on fibronectin $(100 \mu \mathrm{g} / \mathrm{ml}, 2 \mathrm{~h})$ then doublestained with anti- $\alpha^{2} \mathrm{mAb}$ (left panels) and polyclonal anti-phosphotyrosine antibody (right panels) as described in Figure 4. Pictures are at $1000 \times$ magnification.
(Kassner et al., 1994). Figure 7B shows another representative experiment, demonstrating that the $\mathrm{X} 2 \mathrm{C} 0-\mathrm{A}$ and $\mathrm{X} 2 \mathrm{C} 0$-AA mutants utilize $\mathrm{Mg}^{2+}$ a little more efficiently than $\mathrm{X} 2 \mathrm{CO}$ (shown in Figure 7A) but substantially less efficiently than wild-type $\mathrm{X} 2 \mathrm{C} 2$. The results from several adhesion assays are summarized in Table 2, and in each case the efficiency of divalent cation utilization, relative to wild-type $\alpha^{2}$, is presented. As indicated, $\mathrm{X} 2 \mathrm{C} 0$-A failed to exhibit a significant increase in divalent cation utilization efficiency relative to $\mathrm{X} 2 \mathrm{C} 0$, whereas $\mathrm{X} 2 \mathrm{C} 0-\mathrm{AA}, \alpha^{2}-1133$, and $\alpha^{2}-1134$ all showed notable increases in the ability to utilize divalent cations during adhesion. Also, results from a previous study (Kassner et al., 1994) are listed showing efficiencies of divalent cation utilization for X2C0,1136, 1139, and 1146.

In Figure 8, both the efficiency of divalent cation utilization during adhesion assays (ED50 ratio) and the estimated percentage of cells forming FACs on fibronectin (from two separate experiments) are plotted for each $\alpha^{2}$ mutant. Notably, there is a striking inverse correlation between the two functions. Compared to the X2C0 mutant, only one to two additional amino acids were sufficient to partially restore adhesive activity and also suppress indiscriminate FAC localization, whereas four to seven amino acids were sufficient to maximize both functions.

As seen by comparing Figure $8, A$ and $B$, the presence of one alanine residue ( $\mathrm{X} 2 \mathrm{C} 0-\mathrm{A})$ was not as effective as one lysine residue $\left(\alpha^{2}-1133\right)$. However, the presence of two alanines yielded both diminished recruitment into FACs on fibronectin and increased adhesion (Figure 8A). This effect of two alanines (X2C0-AA) was almost comparable to the effect of Lys-Tyr $\left(\alpha^{2}-1136\right)$ on FAC recruitment and adhesion (Figure 8A). Together these results suggest that the mechanisms by which the $\alpha^{2}$ cytoplasmic domain regulates adhesive activity and recruitment into FACs may be closely related.

\section{Cytoplasmic Domain Effects on Echovirus Binding and Infection}

Previously, it was shown that echovirus 1 and 8 bound to cells in a VLA-2-dependent manner (Bergelson et al., 1992, 1993b). The mechanisms by which VLA-2 binds echovirus and collagen are quite distinct (Bergelson $e t$ al., 1993a), even though both echovirus 1 and collagen bind to the I domain within the $\alpha^{2}$ subunit (Bergelson et al., 1994). To assess whether the $\alpha^{2}$ cytoplasmic do- 

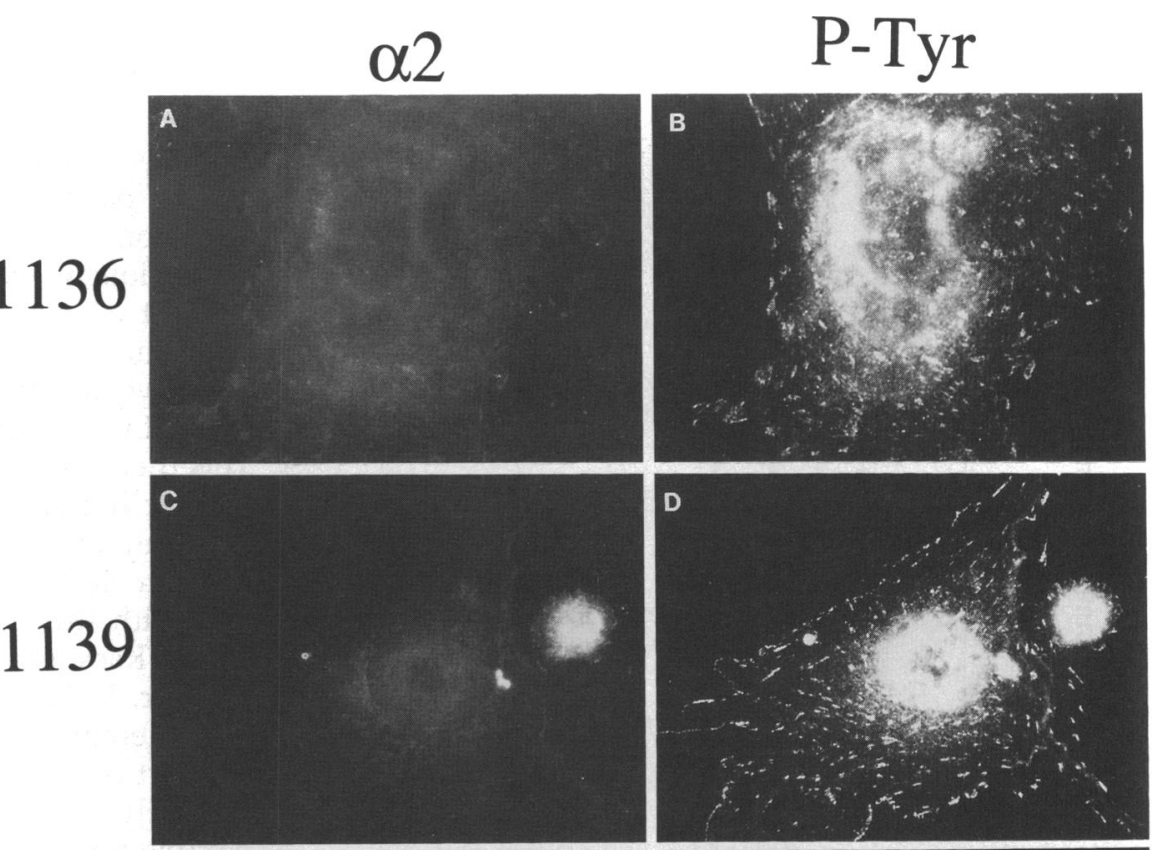

Figure 6. Recruitment of longer $\alpha^{2}$ mutants into FACs on fibronectin. CHO cells were transfected with $\alpha^{2}-1136$ (A and B), $\alpha^{2}-1139$ (C and D), and $\alpha^{2}-1146$ (E and F). Cells were cultured on fibronectin $(100 \mu \mathrm{g} / \mathrm{ml}, 2 \mathrm{~h})$, then double stained with anti- $\alpha^{2} \mathrm{mAb}$ (left panels) and polyclonal anti-phosphotyrosine antibody (right panels) as described in Figure 4. Pictures are at $1000 \times$ magnification.
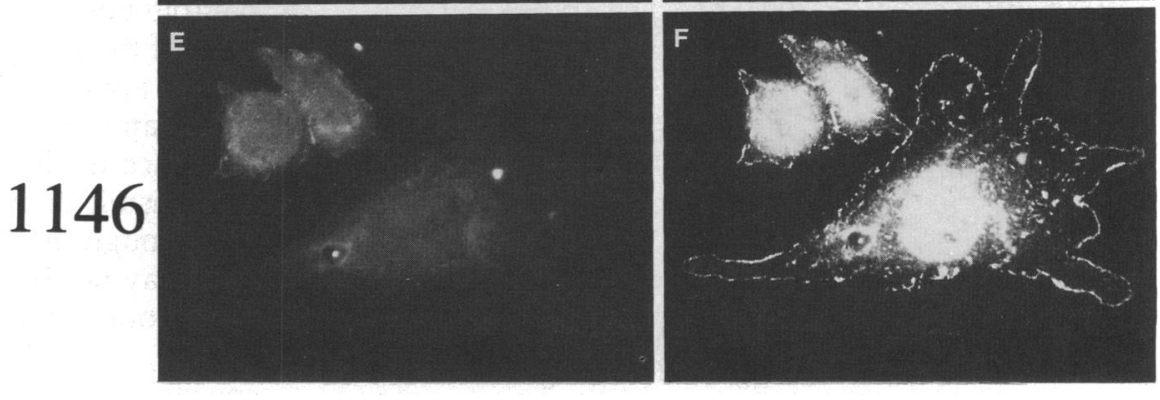

main plays a role in echovirus binding or in subsequent infection and replication events, wild-type and mutated $\alpha^{2}$ proteins were analyzed in $\mathrm{CHO}$ cells. As shown in Figure 9, echovirus 1 bound at a substantial level to $\alpha^{2}$ transfected $\mathrm{CHO}$ cells, and this binding was not altered by complete $(\mathrm{X} 2 \mathrm{C} 0)$ or partial $\left(\alpha^{2}-1139\right)$ deletion of the $\alpha^{2}$ tail. Confirming the VLA-2 specificity of virus binding, no binding was observed for $\mathrm{CHO}$ cells mocktransfected with the $\mathrm{p} 901$ vector alone.

Also, virus infection and replication within $\alpha^{2}$-transfected $\mathrm{CHO}$ cells occurred to a similar extent, regardless of whether the $\alpha^{2}$ tail was deleted or exchanged (Figure 10). As shown after exposure to echovirus 8 , the virus titer increased $\sim 100$-fold (from $10^{4}$ to $10^{6}$ ) for each $\alpha^{2}$ mutant over a 5-d period, whereas no such increase was seen for $\mathrm{CHO}$ cells mock-transfected with the p901 vector alone.

\section{DISCUSSION}

In this study we have used a variety of integrin $\alpha^{2}$ cytoplasmic domain mutants to establish that the same short region within the cytoplasmic domain simulta- neously restricts indiscriminate integrin recruitment into FACs and maintains optimal integrin adhesive activity. Thus, cytoskeletal interactions leading to ligand-independent recruitment into FACs may at the same time be suppressing cell adhesion.

\section{Cytoplasmic Domain Effects on Integrin Localization}

Whereas the $\alpha^{2}$ cytoplasmic domain did not hinder the VLA-2-mediated initiation of FACs when $\mathrm{CHO}$ cells were spread on collagen, it did prevent VLA-2 from being recruited indiscriminately into FACs (e.g., when $\mathrm{CHO}$ cells were spread on fibronectin or vitronectin). In this way, the $\alpha^{2}$ cytoplasmic domain resembles the tails of the integrin $\alpha^{\mathrm{IIb}}$ and $\alpha^{1}$ subunits, which have also been shown to prevent indiscriminate recruitment into FACs (Briesewitz et al., 1993; Ylänne et al., 1993). Presumably, these $\alpha$ tails act as negative regulators, blocking the constitutive localization activity present in the $\beta_{1}$ chain (LaFlamme et al., 1992).

To mediate this negative regulatory activity, it appears that the $\alpha$ chain must be of sufficient length, but no specific sequence motif is required. Within the $\alpha^{2}$ tail, 


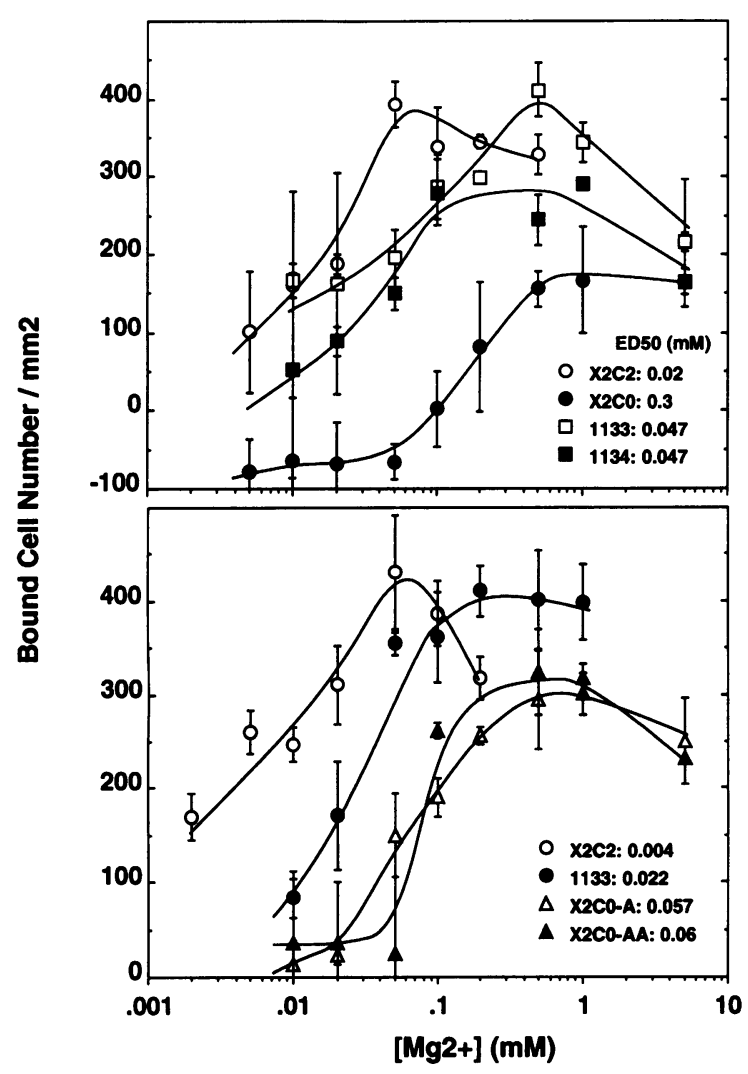

Figure 7. Divalent cation titration effects on adhesion of $\alpha^{2}$-CHO transfectants to collagen. $\mathrm{CHO}$ cells expressing various mutated $\alpha^{2}$ constructs were tested for adhesion to collagen $(5 \mu \mathrm{g} / \mathrm{ml})$ in two separate experiments at seven to eight different $\mathrm{Mg}^{2+}$ concentrations. From these divalent cation titration curves, values for maximal and half-maximal adhesion were estimated and used to determine the cation concentration (ED50 value) at which half-maximal adhesion was attained.

only four to seven residues were sufficient to prevent $\alpha^{2}$ localization into FACs on fibronectin, and as few as one to two residues were sufficient to give partial activity. Furthermore, substitution of residues normally found in $\alpha^{2}$ (Lys-Tyr replaced by Ala-Ala) yielded a construct with nearly as much activity. The lack of a specific sequence requirement also explains how the $\alpha^{2}$, $\alpha^{\mathrm{IIb}}$, and $\alpha^{1}$ tails may function similarly despite marked sequence differences.

\section{Cytoplasmic Domain Effects on Cell Adhesion}

We (Kassner and Hemler, 1993; Kawaguchi and Hemler, 1993) and others (Shaw and Mercurio, 1993; Filardo and Cheresh, 1994; O'Toole et al., 1994) have demonstrated previously that $\alpha$ chain cytoplasmic domains can play a positive role in the regulation of cell adhesion mediated by integrins. More recently, we have found that only four to seven $\alpha^{2}$ or two to six $\alpha^{4}$ cytoplasmic domain residues (after the highly conserved GFFKR motif) can have a positive effect on cell adhesion, with only six to seven residues required for maximal effect (Kassner et al., 1994). Here we have extended those findings to show that even one to two $\alpha^{2}$ residues can have a partial positive effect on VLA-2-mediated cell adhesion.

Previously, we had found that adhesive activity was not lost when key $\alpha^{4}$ residues were mutated to alanine (Kassner et al., 1994). Here we have found that similar adhesive activity is retained when the first two $\alpha^{2}$ residues (Lys-Tyr) after GFFKR are replaced with Ala-Ala. Together these results support the conclusion that a specific $\alpha$ chain "pro-adhesion" motif does not exist, and they argue against the proposed need for a $\beta$ turn in the $\alpha$ chain tail (Filardo and Cheresh, 1994). Consistent with this conclusion, the $\alpha^{2}, \alpha^{4}, \alpha^{5}$ (Chan et al., 1992; Kassner and Hemler, 1993; Kawaguchi and Hemler, 1993), $\alpha^{6 \mathrm{~A}}$, and $\alpha^{6 \mathrm{~B}}$ (Delwel et al., 1993; Shaw and Mercurio, 1993) tails appear to interchangeably support cell adhesion, despite their diverse sequences. Similarly, the tails of $\alpha^{5}, \alpha^{2}, \alpha^{6 \mathrm{~A}}$, and $\alpha^{6 \mathrm{~B}}$ made comparable positive contributions toward the high affinity state of the $\alpha^{\mathrm{IIb}} \beta_{3}$ integrin (O'Toole et al., 1994). In general, it appears that having a length of at least five to seven amino acids may be more critical than specific sequence in determining the contributions of $\alpha$ chain cytoplasmic domains toward integrin adhesive function.

Although they are highly interchangeable, all $\alpha$ chain tails may not be identical in their contributions toward inside-out signaling. In one recent study, the tails of $\alpha^{2}$, $\alpha^{5}, \alpha^{6 \mathrm{~A}}$, and $\alpha^{6 \mathrm{~B}}$ supported expression of an activationspecific epitope on chimeric $\alpha^{\mathrm{Ib}} \beta_{3}$ integrin, whereas the tails of $\alpha^{\mathrm{v}}, \alpha^{\mathrm{II}}, \alpha^{\mathrm{M}}$, and $\alpha^{\mathrm{L}} \operatorname{did}$ not (O'Toole et al., 1994). Nonetheless, another study showed that deletion of the $\alpha^{\mathrm{v}}$ tail still caused diminished adhesive activity (Filardo and Cheresh, 1994), indicating that it can play a positive inside-out signaling role. Thus it seems that $\alpha$ chain tail deletion effects on cell adhesion may not absolutely correlate with effects on integrin activation states measured by antibodies. Also in this regard, deletion of the $\alpha^{4}$ tail caused a marked reduction in adhesive activity without causing a loss in an activation-specific epitope on $\alpha^{4} \beta_{1}$ (Kassner et al., 1994).

\section{Link Between Increased Recruitment into Focal Adhesions and Decreased Cell Adhesion}

Many reports have shown that integrin cytoplasmic domains play pivotal roles in the regulation of integrin adhesive activities (Hayashi et al., 1990; Hibbs et al., 1991a,b; Chen et al., 1992; Ginsberg et al., 1992; Kassner and Hemler, 1993; Kawaguchi and Hemler, 1993; Rabb et al., 1993; Shaw and Mercurio, 1993; Filardo and Cheresh, 1994; Kassner et al., 1994; Hemler et al., 1994; O'Toole et al., 1994), and many other reports have suggested that integrin cytoplasmic domains mediate cytoskeletal interactions (Solowska et al., 
Table 2. Calculation of divalent cation utilization efficiency from adhesion assay ED50 values

\begin{tabular}{|c|c|c|c|c|}
\hline$\alpha^{2}$ mutant & ED50 X2C2 & ED50 mutant & $\begin{array}{c}\text { ED50 ratio } \\
\text { (X2C2/mutant) }\end{array}$ & $\begin{array}{l}\text { Mean of } \\
\text { ratios }\end{array}$ \\
\hline \multirow[t]{4}{*}{$\mathrm{X} 2 \mathrm{CO}-\mathrm{A}^{\mathrm{a}}$} & $0.014^{\mathrm{b}}$ & 0.100 & $0.140^{c}$ & \\
\hline & 0.004 & 0.057 & 0.070 & \\
\hline & 0.020 & 0.012 & 0.167 & \\
\hline & 0.014 & 0.021 & 0.067 & $0.11 \pm 0.05^{\mathrm{d}}$ \\
\hline \multirow[t]{3}{*}{$\mathrm{X} 2 \mathrm{CO}-\mathrm{AA}^{\mathrm{a}}$} & 0.004 & 0.060 & 0.067 & \\
\hline & 0.024 & 0.051 & 0.470 & \\
\hline & 0.050 & 0.130 & 0.380 & $0.31 \pm 0.21$ \\
\hline \multirow[t]{4}{*}{$1133^{a}$} & 0.014 & 0.050 & 0.280 & \\
\hline & 0.021 & 0.070 & 0.300 & \\
\hline & 0.004 & 0.022 & 0.182 & \\
\hline & 0.020 & 0.047 & 0.043 & $0.20 \pm 0.12$ \\
\hline \multirow{3}{*}{$1134^{a}$} & 0.021 & 0.050 & 0.420 & \\
\hline & 0.004 & 0.015 & 0.267 & \\
\hline & 0.020 & 0.047 & 0.426 & $0.37 \pm 0.09$ \\
\hline$X 2 C O(1132)^{a, e}$ & $N=7$ & - & - & $0.11 \pm 0.08$ \\
\hline 1136 & $N=3$ & - & - & $0.81 \pm 0.29$ \\
\hline 1139 & $\mathbf{N}=3$ & - & - & $1.13 \pm 0.33$ \\
\hline 1146 & $N=3$ & - & - & $0.97 \pm 0.46$ \\
\hline $\mathrm{X} 2 \mathrm{C} 2(w t)$ & $N=13$ & - & - & 1.00 \\
\hline
\end{tabular}

a For each mutant, the students T-test was used to determine whether the ED50 value was significantly different from wild-type (X2C2) ED50 values determined in the same experiment. Those mutants for which $p<0.001$ are marked .

${ }^{b}$ Adhesion assays carried out in the presence of seven to eight different $\mathrm{Mg}^{+2}$ concentrations were used to determine ED50 values (see Figure 7 legend). In each experiment, ED50's were determined for both wildtype (X2C2) and mutant $\alpha^{2}$.

c The ratio of $\mathrm{X} 2 \mathrm{C} 2$ and mutant $\alpha^{2}$ ED50 values represents the divalent cation utilization efficiency of the mutant relative to $\mathrm{X} 2 \mathrm{C} 2$.

${ }^{d}$ For each mutant, the mean of at least three different ED50 ratios from separate experiments is presented in the last column.

' Data for the mutants listed in the bottom part of the Table were presented elsewhere (Kassner et al., 1994), and thus only the mean ED50 ratios are shown.

1989; Hayashi et al., 1990; Marcantonio et al., 1990; LaFlamme et al., 1992; Briesewitz et al., 1993; Ylänne et al., 1993). So far, these two types of observations have not been directly related. Although we do not provide definitive proof of such a relationship, it is suggested by the compelling inverse correlations shown in Figure 8, A and B. Thus we propose that $\alpha$ chain tail deletion exposes a site on the $\beta_{1}$ chain that allows cytoskeletal interactions conducive to recruitment into FACs, and these same interactions have an adverse effect on cell adhesion.

For normal integrins, formation of FACs is usually a postligand binding event of significance during outsidein signaling (e.g., see INTRODUCTION). In contrast, we are proposing that deletion of an $\alpha$ chain tail may lead to critical preligand binding interactions between the $\beta_{1}$ chain and cytoskeletal proteins. Presumably, these interactions could perturb either the conformation or distribution of the integrin, thus resulting in diminished cell adhesion. In this regard, it was recently shown that preexisting variations in integrin cell surface distribution may determine its level of constitutive adhesive activity (Van Kooyk et al., 1994).
The interaction of $\beta_{1}$ with the cytoskeletal protein $\alpha$ actinin is an obvious candidate to cause both diminished cell adhesion and increased FAC localization. Because $\alpha$-actinin may interact with a region of $\beta_{1}$ proximal to the membrane (Otey et al., 1993), the presence of only a few $\alpha$ chain residues could conceivably interfere. However, we were unable to determine whether $\alpha^{2}$ chain deletion caused a change in $\beta_{1}$ chain association with $\alpha$-actinin. Although others have detected $\alpha$-actinin in association with integrins (Otey et al., 1990; Pardi et al., 1992), we were unable to detect $\alpha$-actinin by a combination of immunoprecipitation and immunoblotting.

The model proposed above predicts that if $\beta_{1}$ lacked the capability for localization into FACs, then the deleterious effect of $\alpha$ chain tail deletion on cell adhesion might not be observed. An alternative model is that the positive effect of the $\alpha$ chain tail on cell adhesion does not involve prevention of negative cytoskeletal- $\beta_{1}$ interactions. For example, a limited number of $\alpha$ chain residues after GFFKR may be needed simply to stabilize an integrin conformation optimal for adhesion. Experiments with mutant $\beta_{1}$ constructs are currently underway to attempt to distinguish these two possibilities. 


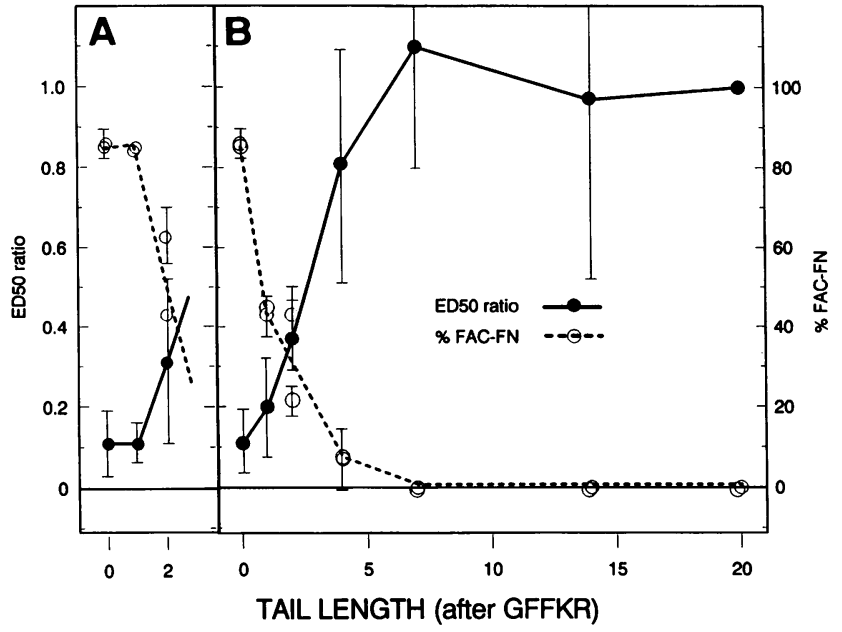

Figure 8. Inverse correlation between the adhesive activity of $\alpha^{2}$ mutants and their localization into FACs on fibronectin. The relative adhesive activities of the various mutant $\alpha^{2}$-CHO cells (reported ED50 ratios from Table 2) are shown in comparison to the estimated percentage of each of the mutant- $\alpha^{2} \mathrm{CHO}$ cells that localized into FACs on fibronectin. In one FAC localization experiment, cells were seeded onto coverslips coated with $100 \mu \mathrm{g} / \mathrm{ml}$ fibronectin then allowed to spread for $2 \mathrm{~h}$. Cells were stained with both anti- $\alpha^{2}$ mAb IIIE9 and anti-phosphotyrosine antibody, and the percentage of cells with $\alpha^{2}$ in FACs was determined as described in MATERIALS AND METHODS and is presented as the mean \pm SD. In another FAC localization experiment, cells were preincubated for $2 \mathrm{~h}$ in MEM $\alpha$ media containing $25 \mu \mathrm{g} / \mathrm{ml}$ of cycloheximide, seeded onto coverslips coated with $20 \mu \mathrm{g} / \mathrm{ml}$ fibronectin, allowed to spread while incubating $2 \mathrm{ad}$ ditional $\mathrm{h}$ in cycloheximide, and then stained to determine the percentage of cells with $\alpha^{2}$ in FACs. Results from both FAC localization experiments are shown for each mutant. A shows data for mutants containing 0, 1, or 2 alanines (added after GFFKR), and B shows data for $\alpha^{2}$ deletion mutants.

A third possibility is that $\alpha$ chain cytoplasmic domain deletion causes extracellular conformational changes that are directly responsible for both diminished cell adhesion and increased localization into FACs. However, at present we do not favor this interpretation because the addition of excess divalent cation (e.g., $\mathrm{Mg}^{2+}$ $\leq 10 \mathrm{mM}$ ) readily overcame the effects of $\alpha$ tail deletion on cell adhesion but failed to prevent indiscriminate localization into FACs.

In other studies, deletion of the $\alpha^{1}$ cytoplasmic domain allowed indiscriminate localization into FACs but was accompanied by only a small decrease in VLA-1-mediated cell adhesion to collagen (Briesewitz et al., 1993). However, cell adhesion was measured in a highly active cellular environment that may have obscured the deletion effect. Based on our previous results (Kassner et al., 1994), we predict that $\alpha^{1}$ chain deletion would cause a more obvious reduction in cell adhesion if tested in the presence of lower divalent cation levels or if tested in a cell that supported lower constitutive adhesive activity. Upon deletion of the $\alpha^{\mathrm{Ib}}$ cytoplasmic domain (after GFFKR), indiscriminate localization of $\alpha^{\mathrm{IIb}} \beta_{3}$ into FACs

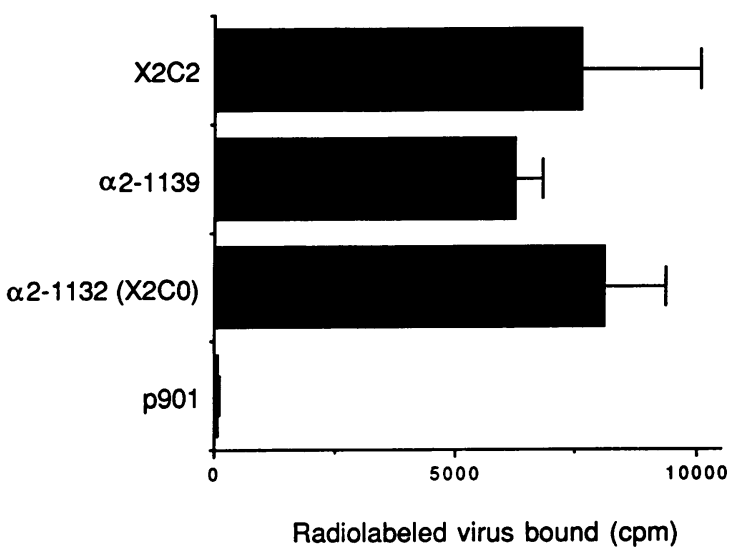

Figure 9. Echovirus 1 binding to $\mathrm{CHO}$ cells expressing $\alpha^{2} \mathrm{C}$-terminal mutants. $\mathrm{CHO}$ cell monolayers were dispersed with PBS containing $2.5 \mathrm{mM}$ EDTA, and then after washing, $5 \times 10^{5}$ cells in Eppendorf tubes were incubated for $1 \mathrm{~h}$ at room temperature with ${ }^{35} \mathrm{~S}$-methioninelabeled echovirus $1(28000 \mathrm{cpm})$. The virus was prepared as described previously (Bergelson et al., 1993b). After washing to remove unbound virus, cells were dissolved for scintillation counting. The graph shows the mean of triplicate determinations for virus binding (cpm) \pm SD.

was observed, but cell adhesion was not comprehensively studied (Ylänne et al., 1993).

\section{Cytoplasmic Domain Effects on Echovirus Binding and Infection}

Previously, we showed that echovirus binding is not altered by $\alpha^{2}$ cytoplasmic domain exchange (Bergelson

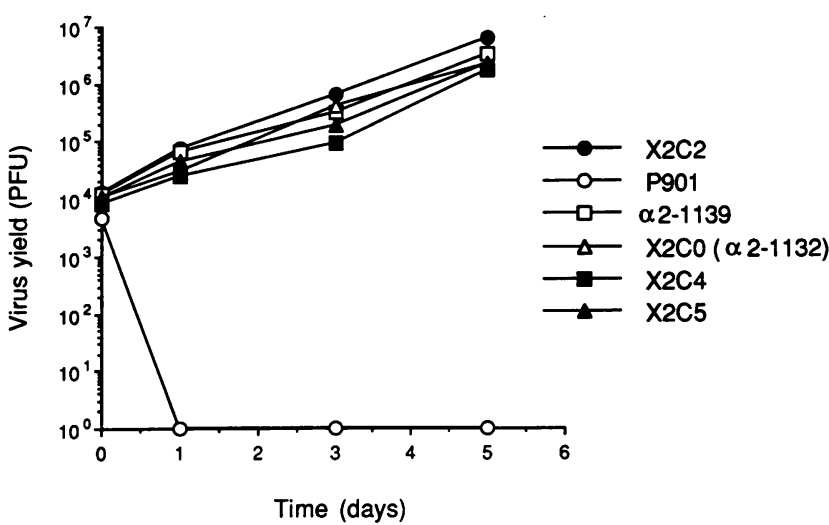

Figure 10. Echovirus 8 infection of $\mathrm{CHO}$ cells expressing $\alpha^{2} \mathrm{C}$-terminal mutants. After 50000 cells were plated in 12-well tissue culture plates and allowed to grow overnight, 100000 plaque-forming units (PFU) of echovirus 8 were added to each well and allowed to adhere for $1 \mathrm{~h}$ at room temperature. Unattached virus was removed by extensive washing; then cells were incubated at $37^{\circ} \mathrm{C}$. At $0 \mathrm{~h}$, and on days 1,3 , and 5 , cultures were frozen and thawed four times to release cell-associated virus particles, and virus titers were determined by plaque assay as described previously (Bergelson et al., 1993b). Echovirus 8 was used in this experiment instead of echovirus 1 because infection and replication in $\mathrm{CHO}$ cells occur at a higher level. Like echovirus 1, echovirus 8 also binds to cells in a VLA-2-dependent manner (Bergelson et al., 1993b). 
et al., 1993a), and now we show that it is similarly unaffected by $\alpha^{2}$ cytoplasmic domain deletion. This latter result indicates that the inside-out signaling mechanisms regulating VLA-2/collagen-laminin interactions do not apply to echovirus binding, even though both types of ligand may bind to the VLA-2 I-domain (Bergelson et al., 1993a; Kamata et al., 1994).

Because deletion or exchange of the $\alpha^{2}$ cytoplasmic domain can have dramatic effects on FAC localization (shown here) and on postligand binding events such as cell migration and collagen gel contraction (Chan et al., 1992), we hypothesized that echovirus infection and replication might also be affected. However, the lack of any effects of $\alpha^{2}$ deletion or exchange on virus uptake and replication further dissociates VLA-2/collagenlaminin interaction mechanisms from VLA-2-echovirus mechanisms.

Thus, echovirus uptake and replication either do not utilize VLA-2 or utilize VLA-2 in mechanisms not involving the $\alpha$ chain tail. Integrin-dependent uptake of adenovirus has been theorized to involve integrin recycling through coated pits (White, 1993). Because the integrin $\beta_{1}$ chain contains two NPXY motifs, possibly involved in receptor recycling through coated pits (Rabb et al., 1993), it is conceivable that echovirus could utilize a similar mechanism independent of the $\alpha$ chain. This hypothesis remains to be tested.

In conclusion, we have found that the mechanisms regulating VLA-2 adhesive activity and restricting VLA2 subcellular localization utilize the same small $\alpha^{2}$ cytoplasmic domain region proximal to the membrane. From this we suggest that the $\alpha$ cytoplasmic domain could exert its regulatory effect on integrin adhesive function by modulating $\beta$ subunit interactions with cytoskeletal proteins. In contrast, VLA-2-dependent echovirus binding and infection are completely unaffected by $\alpha^{2}$ cytoplasmic domain deletion or exchange and thus are regulated by separate mechanisms.

\section{ACKNOWLEDGMENTS}

This work was supported by National Institutes of Health Grants GM-46526 (to M.E.H) and AI-31628 (to R.W.F.), funding from the DFCI-Sandoz Drug Discovery program (to M.E.H), and a fellowship from the Hood Foundation (to J.M.B.).

\section{REFERENCES}

Bauer, J.S., Varner, J., Schreiner, C., Kornberg, L., Nicholas, R., and Juliano, R.L. (1993). Functional role of the cytoplasmic domain of the integrin $\alpha 5$ subunit. J. Cell Biol. 122, 209-221.

Bergelson, J.M., Chan, B.M.C., Finberg, R.W., and Hemler, M.E. (1993a). The integrin VLA-2 binds Echovirus 1 and extracellular matrix ligands by different mechanisms. J. Clin. Invest. 92, 232-239.

Bergelson, J.M., Shepley, M.P., Chan, B.M.C., Hemler, M.E., and Finberg, R.W. (1992). The integrin VLA-2 is an echovirus receptor. Science $255,1718-1720$.

Bergelson, J.M., St. John, N., Kawaguchi, S., Chan, M., Stubal, H., Modlin, J., and Finberg, R.W. (1993b). Infection by echoviruses 1 and
8 depends on the $\alpha 2$ subunit of human VLA-2. J. Virol. $67,6847-$ 6852 .

Bergelson, J.M., St. John, N., Kawaguchi, S., Pasqualini, R., Berdichevsky, F., Hemler, M.E., and Finberg, R.W. (1994). The I domain is essential for echovirus 1 interaction with VLA-2. Cell Adh. \& Comm. (in press).

Briesewitz, R., Kern, A., and Marcantonio, E.E. (1993). Ligand-dependent and -independent integrin focal contact localization: the role of the $\alpha$ chain cytoplasmic domain. Mol. Biol. Cell 4, 593-604.

Brown, P.J., and Juliano, R.L. (1985). Selective inhibition of fibronectinmediated cell adhesion by monoclonal antibodies to a cell-surface glycoprotein. Science 228, 1448-1451.

Brown, P.J., and Juliano, R.L. (1988). Monoclonal antibodies to distinctive epitopes on the $\alpha$ and $\beta$ subunits of the fibronectin receptor. Exp. Cell Res. 177, 303-318.

Chan, B.M.C., Kassner, P.D., Schiro, J.A., Byers, H.R., Kupper, T.S., and Hemler, M.E. (1992). Distinct cellular functions mediated by different VLA integrin $\alpha$ subunit cytoplasmic domains. Cell $68,1051-$ 1060.

Chan, B.M.C., Matsuura, N., Takada, Y., Zetter, B.R., and Hemler, M.E. (1991). In vitro and in vivo consequences of VLA-2 expression on rhabdomyosarcoma cells. Science 251, 1600-1602.

Chen, Y.P., Djaffar, I., Pidard, D., Steiner, B., Cieutat, A.M., Caen, J.P., and Rosa, J.P. (1992). Ser-752 > Pro mutation in the cytoplasmic domain of integrin $\beta_{3}$ subunit and defective activation of platelet integrin $\alpha_{\mathrm{IIb}} \beta_{3}$ (glycoprotein IIb-IIIa) in a variant of Glanzmann thrombasthenia. Proc. Natl. Acad. Sci. USA 89, 10169-10173.

Chen, F.A., Repasky, E.A., and Bankert, R.B. (1991). Human lung tumor-associated antigen identified as an extracellular matrix adhesion molecule. J. Exp. Med. 173, 1111-1119.

Danilov, Y.N., and Juliano, R.L. (1989). Phorbol ester modulation of integrin-mediated cell adhesion: a postreceptor event. J. Cell Biol. 108, 1925-1933.

Delwel, G.O., Hogervorst, F., Kuikman, I., Paulsson, M., Timpl, R., and Sonnenberg, A. (1993). Expression and function of the cytoplasmic variants of the integrin $\alpha 6$ subunit in transfected $\mathrm{K} 562$ cells. J. Biol. Chem. 268, 25865-25875.

Elices, M.J., and Hemler, M.E. (1989). The human integrin VLA-2 is a collagen receptor on some cells and a collagen/laminin receptor on others. Proc. Natl. Acad. Sci. USA 86, 9906-9910.

Elices, M.J., Osborn, L., Takada, Y., Crouse, C., Luhowskyj, S., Hemler, M.E., and Lobb, R.R. (1990). VCAM-1 on activated endothelium interacts with the leukocyte integrin VLA-4 at a site distinct from the VLA-4/fibronectin binding site. Cell 60, 577-584.

Faull, R.J., Kovach, N.L., Harlan, J.M., and Ginsberg, M.H. (1994). Stimulation of integrin-mediated adhesion of $\mathrm{T}$ lymphocytes and monocytes: two mechanisms with divergent biological consequences. J. Exp. Med. 179, 1307-1316.

Filardo, E.J., and Cheresh, D.A. (1994). A $\beta$ turn in the cytoplasmic tail of the integrin $\alpha \mathrm{v}$ subunit influences conformation and ligand binding of $\alpha v \beta 3$. J. Biol. Chem. 269, 4641-4647.

Giancotti, F.G., and Ruoslahti, E. (1990). Elevated levels of the $\alpha^{5} \beta_{1}$ fibronectin receptor suppress the transformed phenotype of chinese hamster ovary cells. Cell 60, 849-859.

Ginsberg, M.H., Du, X., and Plow, E.F. (1992). Inside-out integrin signalling. Curr. Opin. Cell Biol. 4, 766-771.

Hayashi, Y., Haimovich, B., Reszka, A., Boettiger, D., and Horwitz, A. (1990). Expression and function of chicken integrin beta-1 subunit and its cytoplasmic domain mutants in mouse NIH 3T3 cells. J. Cell Biol. 110, 175-184. 
Hemler, M.E., Huang, C., and Schwarz, L. (1987). The VLA protein family. Characterization of five distinct cell surface heterodimers each with a common 130,000 molecular weight $\beta$ subunit. J. Biol. Chem. 262, 3300-3309.

Hemler, M.E., and Strominger, J.L. (1982). Characterization of antigen recognized by the monoclonal antibody (4F2): different molecular forms on human T and B lymphoblastoid cell lines. J. Immunol. 129, 623-628.

Hemler, M.E., Weitzman, J.B., Pasqualini, R., Kawaguchi, S., Kassner, P.D., and Berdichevsky, F.B. (1994). Structure, biochemical properties, and biological functions of integrin cytoplasmic domains. In: Integrin: The Biological Problem, ed. Y. Takada, Ann Arbor, MI: CRC Press, (in press).

Hibbs, M.L., Jakes, S., Stacker, S.A., Wallace, R.W., and Springer, T.A. (1991a). The cytoplasmic domain of the integrin lymphocyte function-associated antigen $1 \beta$ subunit: sites required for binding to intercellular adhesion molecule 1 and the phorbol ester-stimulated phosphorylation site. J. Exp. Med. 174, 1227-1238.

Hibbs, M.L., Xu, H., Stacker, S.A., and Springer, T.A. (1991b). Regulation of adhesion to ICAM-1 by the cytoplasmic domain of LFA-1 integrin beta subunit. Science 251, 1611-1613.

Hynes, R.O. (1992). Integrins: versatility, modulation and signalling in cell adhesion. Cell 69, 11-25.

Kamata, T., Puzon, W., and Takada, Y. (1994). Identification of putative ligand binding sites within I domain of integrin $\alpha 2 \beta 1$ (VLA-2, CD49b/ CD29). J. Biol. Chem. 269, 9659-9663.

Kassner, P.D., and Hemler, M.E. (1993). Interchangeable alpha chain cytoplasmic domains play a positive role in control of cell adhesion mediated by VLA-4, a $\beta_{1}$-integrin. J. Exp. Med. 178, 649-660.

Kassner, P.D., Kawaguchi, S., and Hemler, M.E. (1994). Minimum $\alpha$ chain sequence needed to support integrin-mediated adhesion. J. Biol. Chem. 269, 19859-19867.

Kawaguchi, S., and Hemler, M.E. (1993). Role of the $\alpha$ subunit cytoplasmic domain in regulation of adhesive activity mediated by the integrin VLA-2. J. Biol. Chem. 268, 16279-16285.

LaFlamme, S.E., Akiyama, S.K., and Yamada, K.M. (1992). Regulation of fibronectin receptor distribution. J. Cell Biol. 117, 437-447.

Lemke, H., Hammerling, G.J., Hohmann, C., and Rajewsky, K. (1978). Hybrid cell lines secreting monoclonal antibody specific for major histocompatibility antigens of the mouse. Nature 271, 249-251.

Marcantonio, E.E., Guan, J., Trevithick, J.E., and Hynes, R.O. (1990). Mapping of the functional determinants of the integrin beta- 1 cytoplasmic domain by site-directed mutagenesis. Cell Regul. 1, 597-604.

O'Toole, T.E., Katagiri, Y., Faull, R.J., Peter, K., Tamura, R.N., Quaranta, V., Loftus, J.C., Shattil, S.J., and Ginsberg, M.H. (1994). Integrin cytoplasmic domains mediate inside-out signal transduction. J. Cell Biol. 124, 1047-1059.

O'Toole, T.E., Mandelman, D., Forsyth, J., Shattil, S.J., Plow, E.F., and Ginsberg, M.H. (1991). Modulation of the affinity of integrin $\alpha \mathrm{IIb} \beta 3$ (GPIlb-IIIa) by the cytoplasmic domain of $\alpha \mathrm{IIb}$. Science 254 , 845-847.

Otey, C.A., Pavalko, F.M., and Burridge, K. (1990). An interaction between $\alpha$-actinin and the $\beta 1$ integrin subunit in vitro. J. Cell Biol. 111, 721-729.
Otey, C.A., Vasquez, G.B., Burridge, K., and Erickson, B.W. (1993). Mapping of the $\alpha$-actinin binding site within the $\beta_{1}$ integrin cytoplasmic domain. J. Biol. Chem. 268, 21193-21197.

Pardi, R., Inverardi, L., Rugarli, C., and Bender, J.R. (1992). Antigenreceptor complex stimulation triggers protein kinase $\mathrm{C}$-dependent CD11a/CD18-cytoskeleton association in T lymphocytes. J. Cell Biol. 116, 1211-1220.

Pasqualini, R., Bodorova, J., Ye, S., and Hemler, M.E. (1993). Study of the structure, function and distribution of $\beta_{5}$ integrins using novel anti- $\beta_{5}$ monoclonal antibodies. J. Cell Sci. 105, 101-111.

Pasqualini, R., and Hemler, M.E. (1994). Contrasting roles for integrin $\beta 1$ and $\beta 5$ cytoplasmic domains in subcellular localization, cell proliferation, and cell migration. J. Cell Biol. 125, 447-460.

Pischel, K.D., Hemler, M.E., Huang, C., Bluestein, H.G., and Woods, V.L. (1987). Use of the monoclonal antibody $12 \mathrm{~F} 1$ to characterize the differentiation antigen VLA-2. J. Immunol. 138, 226-233.

Rabb, H., Michishita, M., Sharma, C.P., Brown, D., and Arnaout, M.A. (1993). Cytoplasmic tails of human complement receptor type 3 (CR3, CD11b/CD18) regulate ligand avidity and the internalization of occupied receptors. J. Immunol. 151, 990-1002.

Shaw, L.M., Lotz, M.M., and Mercurio, A.M. (1993). Inside-out integrin signalling in macrophages: analysis of the role of the $\alpha 6 \mathrm{~A} \beta 1$ and $\alpha 6 \mathrm{~B} \beta 1$ integrin variants in laminin adhesion by cDNA expression in an $\alpha 6$ integrin-deficient macrophage cell line. J. Biol. Chem. 268, 11401-11408.

Shaw, L.M., and Mercurio, A.M. (1993). Regulation of $\alpha 6 \beta 1$ integrin laminin receptor function by the cytoplasmic domain of the $\alpha 6$ subunit. J. Cell Biol. 123, 1017-1025.

Solowska, J., Edelman, J.M., Albelda, S.M., and Buck, C.A. (1991). Cytoplasmic and transmembrane domains of integrin $\beta_{1}$ and $\beta_{3}$ subunits are functionally interchangeable. J. Cell Biol. 114, 1079-1088.

Solowska, J., Guan, J.-L., Marcantonio, E.E., Trevithick, J.E., Buck, C.A., and Hynes, R.O. (1989). Expression of normal and mutant avian integrin subunits in rodent cells. J. Cell Biol. 109, 853-861.

Springer, T.A. (1990). Adhesion receptors of the immune system. Nature 346, 425-434.

Takada, Y., and Hemler, M.E. (1989). The primary structure of the VLA-2/collagen receptor $\alpha 2$ subunit (platelet GP Ia): homology to other integrins and the presence of a possible collagen-binding domain. J. Cell Biol. 109, 397-407.

Turner, C.E., and Burridge, K. (1991). Transmembrane molecular assemblies in cell-extracellular matrix interactions. Curr. Opin. Cell Biol. 3, 849-853.

Van Kooyk, Y., Weder, P., Heije, K., and Figdor, C.G. (1994). Extracellular $\mathrm{Ca} 2+$ modulates leukocyte function-associated antigen-1 cell surface distribution on T lymphocytes and consequently affects cell adhesion. J. Cell Biol. 124, 1061-1070.

White, J.M. (1993). Integrins as virus receptors. Curr. Biol. 3, 596599.

Ylänne, J., Chen, Y., O'Toole, T.E., Loftus, J.C., Takada, Y., and Ginsberg, M.H. (1993). Distinct functions of integrin $\alpha$ and $\beta$ subunit cytoplasmic domains in cell spreading and formation of focal adhesions. J. Cell Biol. 122, 223-233. 